\title{
TO STUDY THE MORPHOLOGICAL CHANGES SEEN IN STORED BLOOD IN A BLOOD BANK
}

\author{
Priyanka Gupta1 ${ }^{1}$ Rajat Goyal2 ${ }^{2}$ Chayanika Pantola ${ }^{3}$, Sonal Amit ${ }^{4}$
}

1 Junior Resident, Department of Pathology, G.S.V.M Medical College, Kanpur.

${ }^{2}$ Consultant, Department of Ophthalmology, Dr. J. L. Rohtagi Eye Hospital, Kanpur.

${ }^{3}$ Lecturer Department of Pathology, G.S.V.M Medical College, Kanpur.

${ }^{4}$ Lecturer, Department of Pathology, G.S.V.M Medical College, Kanpur.

\begin{abstract}
\section{BACKGROUND}

The viability and functionality of stored human blood cells is an important clinical issue in transfusion. ${ }^{1}$ During storage, in fact preserved blood cells undergo progressive structural and functional changes that may reduce red cell function and viability after transfusion. ${ }^{2}$ Storage has a negative effect on RBC oxygen delivery ${ }^{3}$ and emerging evidence suggests that allogenic RBC infusion may actually harm some recipients. Considerable evidence suggests that transfusion increases the risk of serious complications and death in critically ill patients, especially in patients who are undergoing cardiac surgery. Current research indicated that the RBC storage lesion is responsible for impaired tissue oxygen use, pro-inflammatory and immunomodulatory effects, increased infections, multiple organ system failure and ultimately increased morbidity and mortality. 4

The aim of present study was to evaluate the morphological changes in blood cells due to processing and storage at interval of 1 day, 1 week, 2 weeks, 3 weeks, 4 weeks and 5 weeks and compare with the morphology at the time of collection (day 0).
\end{abstract}

\section{MATERIALS AND METHODS}

The study was conducted on 5000 blood units of blood bank LLRH Hospital, GSVM Medical College Kanpur. Blood collection bags - $350 \mathrm{~mL}$ capacity containing CPDA-1 as anticoagulant were used which were kept in refrigerator at 4-6 degree Celsius.

\section{RESULTS}

On peripheral blood examination, there are significant changes seen in RBC morphology from discocytes to echinocytes to spherocytes with storage up to 35 days of period. The total leucocyte counts were progressively decreased with storage of blood due to degeneration of leucocytes because of processing, repeated handling or fluctuation in temperature. In differential leucocyte count by automated haematology analyzer, there is decrease in granulocyte percentage with increase in lymphocyte percentage, while there is no significant change in MID percentage (MID cells may include less frequently occurring and rare cells correlating to monocytes, eosinophils, basophils, blasts and other precursor white cells in 3-part differential instrument).

\section{CONCLUSION}

Comparison of day 0 versus day at above mentioned interval revealed that there is change in shape of RBC from disc to echinocytes and spherical, i.e. poikilocytosis increases with storage. Also changes in WBC and platelet occur with storage, i.e. decrease in WBC count occurs due to degenerative changes in granulocytes while no change in lymphocytes is seen. Decrease in quality and quantity of platelets with storage. No significant changes were observed in MCV throughout the study.

\section{KEYWORDS}

RBCs, Blood, Storage, CPDA-1.

HOW TO CITE THIS ARTICLE: Gupta P, Goyal R, Pantola C, et al. To study the morphological changes seen in stored blood in a blood bank. J. Evolution Med. Dent. Sci. 2016;5(77):5705-5709, DOI: 10.14260/jemds/2016/1287

\section{INTRODUCTION}

Blood is always considered as essential for the maintenance of life. 5 Blood is stored to achieve a good post-transfusion survival. 5 To attain this, the cellular integrity and chemical components of the blood must be maintained. This keeps blood in a life-like manner in-vitro and maintains its physiological function. Human blood due its multivalent properties has been the centre of considerable interest.

Financial or Other, Competing Interest: None.

Submission 04-05-2016, Peer Review 12-09-2016,

Acceptance 19-09-2016, Published 24-09-2016.

Corresponding Author:

Dr. Priyanka Gupta,

\# E-741, Kamla Nagar Tanki Road,

Agra-282004,

Uttar Pradesh.

E-mail: rajat.kgmu@gmail.com

DOI: $10.14260 /$ jemds $/ 2016 / 1287$
Blood has been regarded as fluid of infinite complexity and the very essence of life.

There is yet no substitute for human blood and its components. Red Blood Cells (RBC) are ideally suited to their primary function of transport of oxygen from lungs to the tissues and carbon dioxide from the tissues to lungs. Red blood cell transfusions are given to raise the haematocrit level in patients with anaemia or to replace losses after an acute bleeding episode.

The modern liquid red blood cell storage systems made RBC units safe, available, effective and affordable for most patients who need transfusion therapy. As the majority of transfused individuals now receive allogenic RBCs 1 to 3 weeks after they are donated, therefore better RBC-storage system hold the possibility of delivering better cells. Gibson introduced a new improved preservative solution in 1957 containing citrate, phosphate, dextrose (CPD) that increases the storage age up to 28 days. 
This storage solution was modified in USA in 1978 by incorporating adenine to citrate phosphate-dextrose and called CPDA1, which is regarded as the latest blood preservative. It increases blood storage time up to 35 days and it is nowadays in every blood bank in the world. 6

The aim of storage system is to counteract damage to the metabolic machinery and the membrane, maintain a concentration of ATP and adenosine to improve posttransfusion viability. Other substances of potential benefit are inorganic phosphate (Both as substrate for the maintenance of organic phosphate compounds and for buffering), and citrate (for anticoagulation buffering and influencing intracellular pH). Mannitol (and sorbitol) had been used for osmotic support and for counteracting spontaneous storage associated haemolysis.

When blood is collected in a standard anticoagulantpreservative solution and stored under blood bank condition, the red cells slowly undergo changes which lead to a loss of red cell viability and capacity to off-load oxygen normally. One of the major source of energy to red cells is the metabolism of glucose to lactate. During liquid storage, the red cells are kept at temperature of $2-80 \mathrm{C}$. At this temperature the metabolism is reduced by 40 times leading to a reduction in normal aging process, but at the same time it also paralyses the red cell membrane function including the membrane associated $\mathrm{Na}+/ \mathrm{K}+$ pump. Thus the cells can no longer actively maintain its high $\mathrm{K}+$ and low $\mathrm{Na}+$ content.

Preservation and long-term storage of Red Blood Cells (RBCs) is needed to ensure a readily available, safe blood supply for transfusion medicine. In blood bank, numerous changes occur in RBCs during storage (collectively referred to as the "storage lesion") that may alter their biological function including delivery of oxygen to cells ${ }^{7}$ that are believed to be responsible for its reduced viability, efficacy and adverse effects associated with transfusion. During storage, ATP decreases in time leading to energetic compromise, loss of membrane stability and morphological and rheological changes including RBC adhesion to the endothelium..$^{8-12}$

\section{AIM}

The aim of present study was to evaluate the morphological changes in blood cells due to processing and storage at interval of 1 day, 1 week, 2 weeks, 3 weeks, 4 weeks and 5 weeks and compare with the morphology at the time of collection (day 0 ).

\section{MATERIAL AND METHODS}

The present study is one and a half years prospective study conducted in the Blood Bank, Dept. of Pathology, GSVM Medical College, Kanpur, from January 2014 to August 2015. The study was conducted on 5000 blood units of blood bank, LLRH Hospital, GSVM Medical College, Kanpur. Blood collection bags - $350 \mathrm{~mL}$ capacity containing CPDA-1 as anticoagulant were used, which were kept in refrigerator at 46 degree Celsius.

After elaborate medical history, necessary physical examination and haemoglobin estimation, the healthy adult donors were accepted and registered. Next phlebotomy was performed after taking written consent from the donor. Appropriate aseptic preparation of donor arm was done to ensure sterility of the area during phlebotomy. Computed electronic monitor was used to ensure accurate collection of blood volumes. The time required for collection of each unit was also recorded.

Volume of blood collected was proportionate to the volume of anticoagulant. Quadruple pack system consisting of single main bag with three attached satellite bags, made of polyvinyl chloride with Di-(2-ethylhexyl) phthalate (DEHP) as plasticizer, was used to prepare and store packed red cells. Whole blood was collected in the anticoagulant solution of citrate, phosphate, dextrose and adenine in volume of $49 \mathrm{~mL}$ for $350 \mathrm{~mL}$ of blood in primary bag.

The dates of collection and expiry, ABO and $\mathrm{Rh}$ (D) group were also written on the label of bag. Donor blood was tested for transfusion transmissible diseases and was screened for hepatitis B surface antigen, anti-HCV antibody, anti-HIV 1 and HIV 2, syphilis and malaria as per guideline of DGHS.

Sampling was performed from five thousand units of whole blood. Samples were collected after gentle mixing by inversion, by sterile sampling procedure in a laminar airflow cabinet (Jove's automation).

The pre-storage whole blood sample before component separation and storage was collected from primary bag immediately after phlebotomy; $50 \mathrm{~mL}$ of each unit was separately stored. This was the Day 0 sample. About $2 \mathrm{~mL}$ of this whole blood sample was taken in dipotassium ethylene diamine tetra-acetic acid EDTA (K2E) vacutainer for morphological examination at mentioned interval or days. The pre-storage sample was considered as control sample for study and statistical analysis.

\section{For Morphological Assessment of Red Cells}

Blood films were stained with Leishman stain and red cell morphology was assessed by light microscopy. Two hundred cells were classified as discocytes, echinocytes or spherocytes.

\section{Blood Film Preparation}

A small drop of blood was placed in the centre line of a clean glass slide about $1 \mathrm{~cm}$ from one end. Then without delay place a spreader in front of the drop at an angle of about 30 degrees to the slide and move it back to make contact with the drop. With a steady movement of the hand, spread the drop of blood along the slide. The blood film was about $3 \mathrm{~cm}$ in length and finished at least $1 \mathrm{~cm}$ before the end of the slide. The films were allowed to dry in the air. The slides were labelled immediately after spreading.

\section{Leishman's Stain}

Weighed out $0.2 \mathrm{~g}$ of the powdered dye and transferred it to a conical flask of $200-250 \mathrm{~mL}$ capacity. Added $100 \mathrm{~mL}$ of methanol and warmed the mixture to 50 degrees Celsius for 15 mins., occasionally shaking it. Allowed the flask to cool and filter. It was then ready for use.

\section{Buffered Water}

Made up $50 \mathrm{~mL}$ of $66 \mathrm{mmol} / \mathrm{L}$ Sorensen's phosphate buffer of the required $\mathrm{pH}$ to 1 litre with a $\mathrm{pH}$ of 6.8. Method: Air dried the film and flooded the slide with the stain. After 2 mins. added double the volume of buffer and stained the film for 5 7 mins. The slide was washed in a stream of water until it had acquired a pinkish tinge (up to 2 mins.). After the back of the slide had been wiped clean, set it up right to dry. The blood 
film was mounted with the glass coverslip and examined under 100x oil immersion.

\section{Statistical Analysis}

The statistical analysis was done using SPSS software for windows. The data were grouped according to the days of collection of samples. Considering the day 0 sample as control, paired ' $\mathrm{t}$ ' test was calculated for day 1 , day 7 , day 14 , day 21, day 28, day 35 and correlation between individual group were analysed with Pearson's Correlation Coefficient (PCC) and a PCC of $<0.05$ was considered as statistically significant.

\section{RESULTS}

Five thousand healthy voluntary donors were selected for phlebotomy. Mean age of the donors was 32 yrs. ranging from 18 to 48 yrs. Among them, 970 were female donors and 4030 males accounting for M:F ratio of 4.15:1.

\begin{tabular}{|c|c|c|c|c|}
\hline $\begin{array}{c}\text { Age } \\
\text { (Year) }\end{array}$ & $\begin{array}{c}\text { No. of } \\
\text { Donors (\%) }\end{array}$ & $\begin{array}{c}\text { Male } \\
\text { Donors }\end{array}$ & $\begin{array}{c}\text { Female } \\
\text { Donors }\end{array}$ & $\begin{array}{c}\text { M:F } \\
\text { Ratio }\end{array}$ \\
\hline $18-28$ & $2210(44.2 \%)$ & 1910 & 300 & $6.4: 1$ \\
\hline $29-38$ & $1430(28.6 \%)$ & 1030 & 400 & $2.6: 1$ \\
\hline $39-48$ & $1360(27.2 \%)$ & 1090 & 270 & $4: 1$ \\
\hline Total & 5000 & $\begin{array}{c}4030 \\
(80.6 \%)\end{array}$ & $\begin{array}{c}970 \\
(19.4 \%)\end{array}$ & $4.15: 1$ \\
\hline \multicolumn{5}{|c|}{ Table 1: Age and Sex Distribution of Donors } \\
\hline
\end{tabular}

Table 1 show that majority of donors were males (80.6\%) and majority donors in our study were of age group 18-28 yrs. old (44.2\%).

\begin{tabular}{|c|c|c|c|}
\hline $\begin{array}{c}\text { Blood } \\
\text { Group }\end{array}$ & $\begin{array}{c}\text { No. of } \\
\text { Donors (\%) }\end{array}$ & $\begin{array}{c}\text { No. of Male } \\
\text { Donors }\end{array}$ & $\begin{array}{c}\text { No. of Female } \\
\text { Donors }\end{array}$ \\
\hline B & $2000(40 \%)$ & 1560 & 440 \\
\hline 0 & $\begin{array}{c}1660 \\
(33.2 \%)\end{array}$ & 1340 & 320 \\
\hline A & $980(19.6 \%)$ & 820 & 160 \\
\hline AB & $360(7.2 \%)$ & 310 & 50 \\
\hline \multicolumn{4}{|r|}{ Table 2: ABO Blood Group Distribution among Donors } \\
\hline
\end{tabular}

Table 2 shows that majority of donors were B group (40\%).

\begin{tabular}{|c|c|}
\hline Rh Positive Donors & Rh Negative Donors \\
\hline $89.5 \%$ & $10.5 \%$ \\
\hline \multicolumn{2}{|c|}{ Table 3: Rh Blood Group Distribution among Donors } \\
\hline
\end{tabular}

Table 3 shows that majority of donors were Rh positive (89.5\%) and Rh negative donors in our study were 9.2\%.

\section{PBS Examination}

Blood films were prepared and stained with Leishman's stain and red cell morphology was assessed by light microscopy. Erythrocyte cell membranes undergo morphologic changes during storage, ${ }^{6}$ which results in shape change of RBCs. Two hundred cells were counted and classified as either discocytes, echinocytes or spherocyte.

\begin{tabular}{|c|c|c|c|}
\hline $\begin{array}{c}\text { Days of } \\
\text { Storage }\end{array}$ & $\begin{array}{c}\text { Discocytes } \\
(\mathbf{\% )}\end{array}$ & $\begin{array}{c}\text { Echinocytes } \\
\text { (\%) }\end{array}$ & $\begin{array}{c}\text { Spherocytes } \\
(\%)\end{array}$ \\
\hline Day 0 & $193(96.5)$ & $5(2.5)$ & $2(1)$ \\
\hline Day 1 & $191(95.5)$ & $7(3.5)$ & $2(1)$ \\
\hline Day 7 & $181(90.5)$ & $15(7.5)$ & $4(2)$ \\
\hline Day 14 & $161(80.5)$ & $35(17.5)$ & $4(2)$ \\
\hline Day 21 & $125(62.5)$ & $69(34.5)$ & $6(3)$ \\
\hline Day 28 & $85(42.5)$ & $104(52)$ & $11(5.5)$ \\
\hline Day 35 & $80(40.0)$ & $105(52.5)$ & $15(7.5)$ \\
\hline \multicolumn{4}{|c|}{ Table 4: Mean Value of Red Cell Shape } \\
\hline \multicolumn{4}{|c|}{ Changes during Storage } \\
\hline
\end{tabular}

Table 4 shows that with storage percentage of discocytes decreased and that of echinocytes and spherocytes increased.

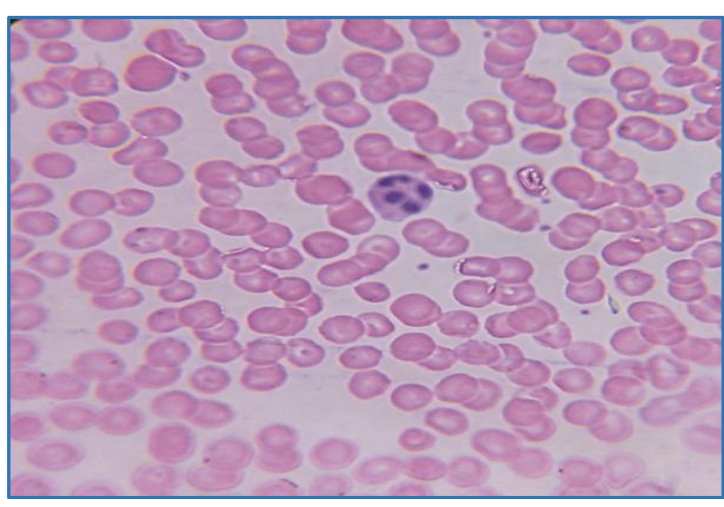

Fig. 1: Day 0 - No Change

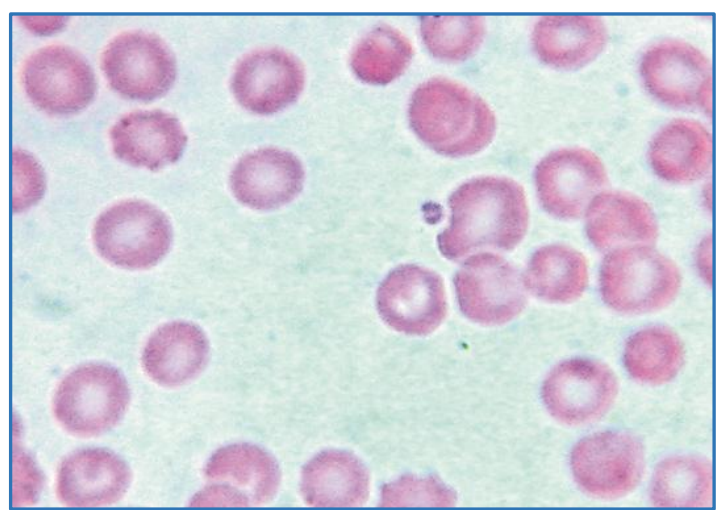

Fig. 2: Day 7 - Few Acanthocytes

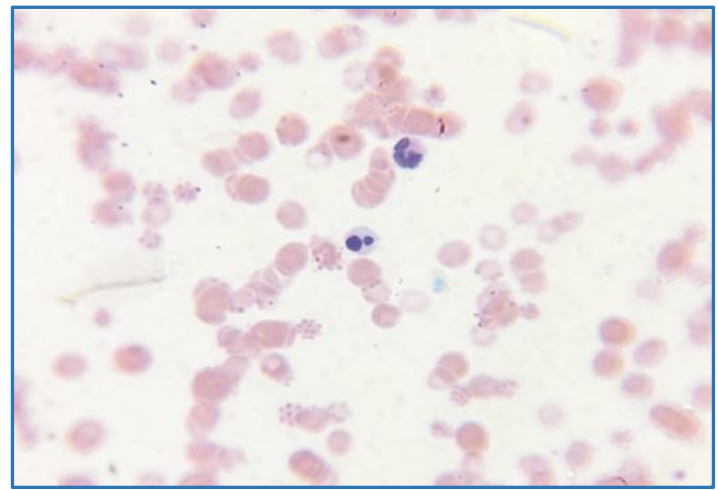

Fig. 3: Day 14 - Acanthocytes and Degeneration in Granulocytes is seen along with Decrease in Granulocytes and Platelets 


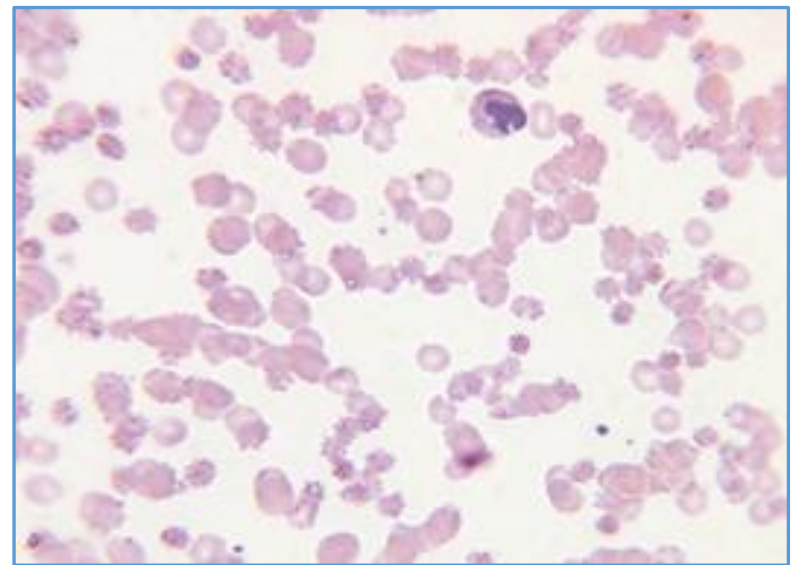

Fig. 4: Day 21 - Increased Acanthocytes and Few Spherocytes

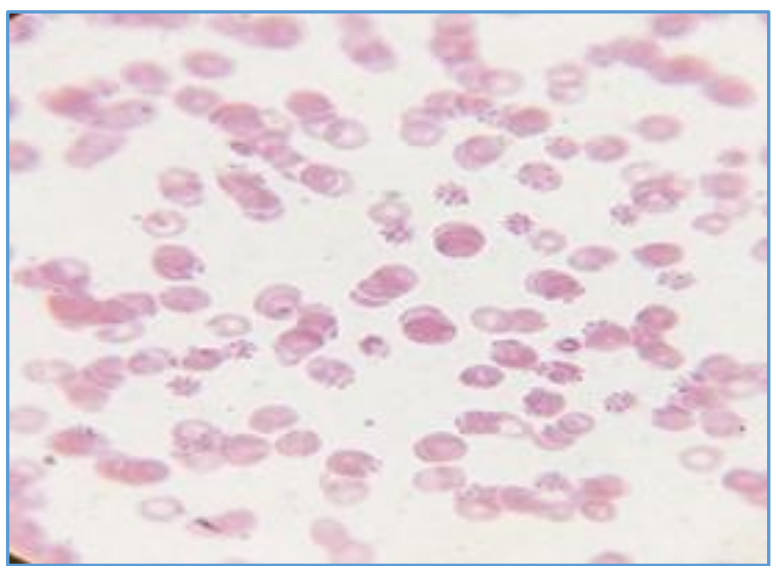

Fig. 5: Day 28 - Marked Increased Acanthocytes and Few Spherocytes

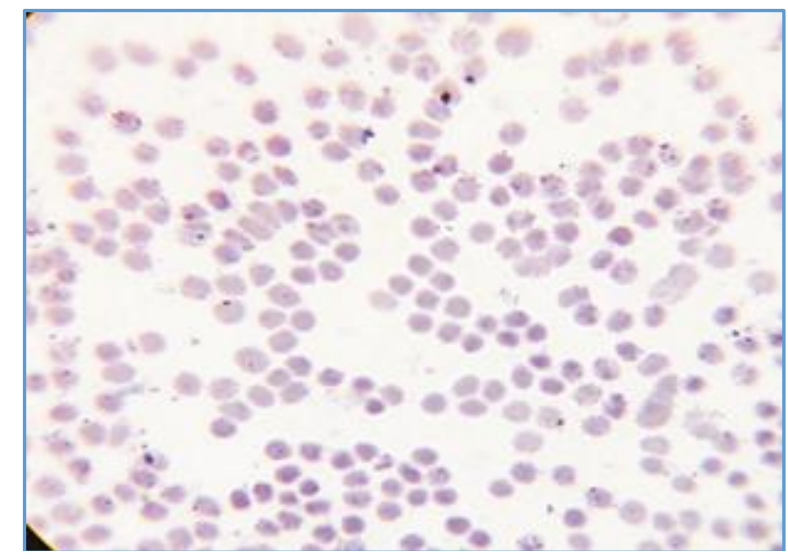

Fig. 6: Day 35 - Marked Increased Acanthocytes and Spherocytes

\begin{tabular}{|c|c|c|}
\hline $\begin{array}{l}\text { Days of } \\
\text { Storage }\end{array}$ & $\begin{array}{c}\text { Mean+SD } \\
\text { (Cells/cumm) }\end{array}$ & $\begin{array}{c}\text { P value }<0.05 \\
\text { (Statistical Significant) }\end{array}$ \\
\hline Day 0 & $7316+2131$ & $\begin{array}{c}<0.0001 \text { (Extremely } \\
\text { Significant) }\end{array}$ \\
\hline Day 1 & $6996+2083$ & \\
\hline Day 7 & $5321+1896$ & $<0.0001$ \\
\hline Day 14 & $3696+1839$ & $<0.0001$ \\
\hline Day 21 & $2054+1712$ & $<0.0001$ \\
\hline Day 28 & $1550+1591$ & $<0.0001$ \\
\hline Day 35 & $1096+1488$ & $<0.0001$ \\
\hline
\end{tabular}

Table 5 shows that mean TLC value decreases with storage of blood.

DLC calculated by automated haematology analyzer.

\begin{tabular}{|c|c|c|c|}
\hline $\begin{array}{c}\text { Days of } \\
\text { Storage }\end{array}$ & $\begin{array}{c}\text { Granulocytes } \\
\text { (\%) }\end{array}$ & $\begin{array}{c}\text { Mid } \\
\text { (\%) }\end{array}$ & $\begin{array}{c}\text { Lymphocytes } \\
\text { (\%) }\end{array}$ \\
\hline Day 0 & 57.07 & 4.06 & 38.86 \\
\hline Day 1 & 32.64 & 3.42 & 63.84 \\
\hline Day 7 & 25.79 & 5.75 & 68.4 \\
\hline Day 14 & 20.27 & 6.52 & 73.226 \\
\hline Day 21 & 14.57 & 7.472 & 77.94 \\
\hline Day 28 & 10.15 & 7.61 & 82.28 \\
\hline Day 35 & 6.35 & 7.24 & 86.46 \\
\hline \multicolumn{2}{|c|}{ Table 6: Variation in Mean DLC Value during Storage } \\
\hline
\end{tabular}

Table 6 shows that granulocytes decreases and mid and lymphocytes increases with storage of blood.

\begin{tabular}{|c|c|c|}
\hline Days of Storage & $\begin{array}{c}\text { Mean+SD } \\
\text { (Lac/cumm) }\end{array}$ & $\begin{array}{c}\text { P value }<0.05 \\
\text { (Statistical } \\
\text { Significant) } \\
\end{array}$ \\
\hline Day 0 & $2.51+0.66$ & $\begin{array}{c}<0.0001 \\
\text { (Extremely Significant) }\end{array}$ \\
\hline Day 1 & $2.13+0.64$ & \\
\hline Day 7 & $1.38+0.53$ & $<0.0001$ \\
\hline Day 14 & $1.05+0.45$ & $<0.0001$ \\
\hline Day 21 & $0.805+0.32$ & $<0.0001$ \\
\hline Day 28 & $0.64+0.28$ & $<0.0001$ \\
\hline Day 35 & $0.27+0.26$ & $<0.0001$ \\
\hline \multicolumn{3}{|c|}{$\begin{array}{l}\text { Table 7: Variation in Mean Platelet Count Value } \\
\text { (Counted Manually on PBS) during Storage }\end{array}$} \\
\hline
\end{tabular}

Table 7 shows that mean platelet count decreases with storage of blood.

\section{DISCUSSION}

Blood units were collected, processed and stored as whole blood at 4-6 degree Celsius in CPDA as anticoagulant for 35 days. This one and a half years based prospective study was undertaken to evaluate the morphological changes.

In our study (Table 1), the number of female donors was higher than female donors of other studies. In our study, $19.4 \%$ donors were female as compared to $7.86 \%$ reported by Majumdar and Ganguly (1999) and 6\% reported in WHO data bank 2008. According to the WHO data bank 2008, Indian females do not believe in donating blood usually, but as the figure in our study is more we can say that the awareness about blood donation is increasing in Indian females.

Microscopic examination of blood smears for changes in red cell morphology during 35 days storage showed progression from normal discocytes through to echinocytes and spherocytes. In our study, no significant change in red cell shape was observed during first week of storage as normal discocytes dominated the blood picture (91-97\%) in Table 4.

During second week (day 14 sample) in Table 4, we observed $17.5 \%$ echinocytes and $2 \%$ spherocytes. Maximum change in shape of red cells was seen in the last two weeks of storage.

On day 35 (Table 4) the percentage of discocytes, echinocytes and spherocytes in our study was $40 \%, 52.5 \%$ and $7.5 \%$ respectively. 
Recently, Karon et al demonstrated that there may be irreversible morphological changes with loss of RBC function which occur early during storage at day 12.13

\section{CONCLUSION}

In present study, comparison of day 0 versus day at above mentioned interval reveals change in shape of RBC from discocytes to echinocytes and spherical, marked degenerative changes in granulocytes while viable lymphocytes persist throughout. These changes ultimately results in decrease in total leucocyte count. There is decrease in viable platelets and change in size of platelets with storage. The release of various chemicals and enzymes, especially proteases from the leucocytes contributes significantly to an increase in red cell haemolysis during storage. Therefore, various leucocyte reduction filters are commercially available to decrease the rate of haemolysis in stored red cell units.

Present study shows that RBCs with duration of storage more than 14-20 days induce lesion on microcirculation and do not increase the consumption of oxygen of cells, which lead to development of multiple organ dysfunction.

With storage, rapid degeneration of leucocytes could lead to immunomodulation related to blood transfusion. Hence, whole blood should be leucodepleted before storage if it must be used beyond one week. ${ }^{14}$

\section{REFERENCES}

1. Park HJ, Ji M, Lee SY, et al. Alterations in cell surface area and deformability of individual human red blood cells in stored blood. http://arxiv.org/abs/1506.05259.

2. Koch CG, Li L, Sessler DI, et al. Duration of red-cell storage and complications after cardiac surgery. N Engl J Med 2008;358(12):1229-39.

3. Bonaventura J. Clinical implications of the loss of vasoactive nitric oxide during red blood cell storage. Proc Natl Acad Sci U S A 2007;104(49):19165-6.

4. Bennett-Guerrero E, Veldman TH, Doctor A, et al. Evolution of adverse changes in stored RBCs. Proc Natl Acad Sci U S A 2007;104(43):17063-8.
5. Ahmed Y, Bashar M. Effect of blood storage on certain hematological parameters. Tikrit Medical Journal 2009;15(1):171-80.

6. Frank SM, Abazyan B, Ono $M$, et al. Decreased erythrocyte deformability after transfusion and the effects of erythrocyte storage duration. Anesth Analg 2013;116(5):975-81.

7. Tinmouth A, Fergusson D, Yee IC, et al. Clinical consequences of red cell storage in the critically ill. Transfusion 2006;46(11):2014-27.

8. Greenwalt TJ, Bryan DJ, Dumaswala UJ. Erythrocyte membrane vesiculation and changes in membrane composition during storage in citrate-phosphatedextrose-adenine-1. Vox Sang 1984;47(4):261-70.

9. Rumsby MG, Trotter J, Allan D, et al. Recovery of membrane micro-vesicles from human erythrocytes stored for transfusion: a mechanism for the erythrocyte discocyte-to-spherocyte shape transformation. Biochem Soc Trans 1977;5(1):126-8.

10. Dem RJ, Gwinn RP, Wiorkowski JJ. Studies on the preservation of human blood. I. Variability in erythrocyte storage characteristics among healthy donors. J Lab Clin Med 1966;67(6):955-65.

11. Berezina TL, Zaets SB, Morgan $C$, et al. Influence of storage on red blood cell rheological properties. J Surg Res 2002;102(1):6-12.

12. Anniss AM, Sparrow RL. Variable adhesion of different red blood cell products to activated vascular endothelium under flow conditions. Am J Hematol 2007;82(6):439-45.

13. Karon BS, Hoyer JD, Stubbs JR, et al. Changes in band 3 oligomeric state precede cell membrane phospholipid loss during blood bank storage of red blood cells. Transfusion 2009;49(7):1435-42.

14. Adias TC, Moore-Igwe B, Jeremiah ZA. Storage related haematological and biochemical changes of CPDA-1 whole blood in a resource limited setting. J Blood Disorders Transf 2012;3:124. 